DOI: $10.31249 / \mathrm{rsm} / 2018.04 .02$

\title{
B.А. Соболев
}

\section{Ф.М. БУРААЦКИЙ И СТАНОВАЕНИЕ ПРАВ И СВОБОА ЧЕАОВЕКА В РОССИИ}

Аннотация. В статье рассматривается деятельность и творчество Федора Михайловича Бурлачкого (1927-2014), посвященные становлению прав и свобод человека в России и в СССР. Обосновывается вывод, что Бурлаикий не просто внес значительный идейный вклад в становление прав и свобод человека в России, но и смог реализовать часть своих предложений на практике.

Ключевые слова: Ф.М. Бурлачүкий, права и свободы человека в России, политическая история России.

Соболев Владимир Андреевич - аспирант

кафедры истории социально-политических учений

факультета политологии Московского государственного

университета имени М.В. Ломоносова. E-mail: sobvlad1992@yandex.ru

V.A. Sobolev. F.M. Burlatsky and Establishment of the Human Rights and Freedoms in Russia

Abstract. The author addresses the political activities and scientific works of Fyodor Burlatsky (1927-2014) showing that Burlatsky not only made a significant ideological contribution to the establishment of human rights and freedoms in Russia, but also was able to implement part of his proposals in practice.

Keywords: Burlatsky, human rights and freedoms in Russia, political history of Russia.

\footnotetext{
Sobolev Vladimir Andreevich - postgraduate student

of the Department of History of Social and Political Studies,

Faculty of Political Science of Lomonosov Moscow State University.

E-mail: sobvlad1992@yandex.ru
}

Вклад Ф.М. Бурлацкого (1927-2014) в разработку проблемы прав и свобод человека в России проанализирован во многих исследованиях российских авторов [6, с. 24-29; 7, с. 101-123; 14, с. 191-206; 16, с. 25-42; 17, с. 124-128]. 
Однако многие положения его работ на эту тему требуют дополнительного изучения.

\section{Исследование Ф.М. Бурлацким процесса становления прав и свобод человека в России}

По мнению Бурлацкого, история становления прав и свобод человека в России уходит корнями в XVIII в., когда в «Наказе» Екатерины II впервые были охарактеризованы права и свободы человека $[8$, с. 9-17; 9, с. 279-299; 10, с. 175-194]: «Парадоксально, но факт, что впервые о неотчуждаемых человеческих правах - о свободе, о равенстве перед законом, о верховенстве закона - русские люди услышали не от кого-нибудь, а от царской власти. Я имею в виду “Наказ” Екатерины II, составленный ею самой и ее сотрудниками и приуроченный к Собору, который должен был собраться для выработки новых законов в европейском духе. "Наказ" изобилует ссылками на французских просветителей, английских, голландских мыслителей XVIII века. Здесь можно найти большие выдержки из произведений Ш. Монтескье, Дж. Локка, Беккариа и многих других представителей школы естественного права, идей равенства и свободы» [3, с. 219].

Далее Бурлацкий отмечает историческую роль преобразований Петра I и Александра II: «Двести лет прошло между двумя взрывами реформаторства Петра I и Александра II. Но, несмотря на дистанцию, тогда решались сходные задачи: налаживание профессионального управления; установление честного правосудия; повышение эффективности хозяйства; просвещение народа. Это говорит о том, как медленно тащилась политическая телега России по ухабам и весям истории. Страна невероятно расширялась на Запад и, особенно, на Восток, а государство оставалось архаичным, феодальным. Но в отличие от Петра, Александр II уже проявлял интерес к правам человека и освобождению крестьян от крепостного рабства» [3, с. 223].

Бурлацкий подчеркивает, что во времена Петра I именно проблема развития прав и свобод человека не рассматривалась, но было проведено «некоторое уравнение сословий перед лицом абсолютной власти. Купечество и городское мещанство получили доступ к образованию и должностям в аппарате управления. Личные качества обретали не меньшее значение, чем принадлежность к знатным родам. Восточный ритуал двора уступил место западным канонам. В среду аристократии стали проникать либеральные западные идеи. Дочь Петра I Елизавета Петровна не случайно отказалась от применения смертной казни. Это был акт, навеянный просветительскими начинаниями Петра Великого» [3, с. 228]. А уже в XIX в. именно реформы Александра II заложили основу для становления прав и свобод человека в России: «освобождение крестьян - земельная реформа; создание местного самоуправления - 
земская (от слова “земля") реформа; реформа печати и образования; учреждение суда присяжных - судебная реформа... Отмена крепостного права явилась первым примером глубокой, социальной реформы “сверху”. В сущности, это был первый исторический шаг к становлению личных прав человека (здесь и далее выделено мной. - В. С.)» [3, с. 228-229].

Бурлацкий отмечает, что проблемы прав и свобод человека: «появились в русской лексике... только в конце XIX и начале XX века. Впервые проблемы правового государства, естественного права рассматриваются в трудах Б.А. Кистяковского, Б.Н. Чичерина, П.И. Новгородцева, Л.И. Петражицкого [18, с. 39-55; 19, с. 166-186; 20, с. 58-119]» [3, с. 235]. В начале XX в. после обнародования Манифеста 17 октября 1905 г., когда в России была избрана первая Государственная дума, «либеральные идеи отстаивала, пожалуй, только одна партия - конституционных демократов, но она не имела значительного влияния ни в Думе, ни в обществе, а тем более в среде необразованного и, как правило, неграмотного крестьянства, а также рабочего класса. Поэтому общественное сознание было совершенно не подготовлено к восприятию прав человека как основы демократического устройства государства. Самая прогрессивная мысль в период революций 1917 года фактически останавливалась перед дверью Учредительного собрания, которое должно было выработать конституцию и заложить основы демократического республиканского строя» [3, с. 236].

По мнению Бурлацкого, самым выдающимся реформатором дореволюционной России был П.А. Столыпин (1862-1911). Занимая сначала пост губернатора, затем председателя Совета министров и министра внутренних дел в начале XX в., Столыпин начал осуществление реформ, которые, «по его словам, ставили целью превращение России в правовое государство. Основой переустройства самодержавия в конституционную монархию Столыпин считал коренное изменение положения крестьянства. Главная его мысль состояла в создании условий для выхода крестьянина из общины и обретения частной собственности на землю, что должно было стать основой его свободы, а затем и конституционного строя в целом. Он провел ряд установлений, которые подготовляли почву для коренной реформы положения крестьянства. В их числе был Указ от 5 октября 1906 года о равноправии крестьян, от 9 ноября о выходе из общины, от 12 августа, 27 августа, 19 сентября, 21 октября о передаче земель крестьянам и т.д. По инициативе Столыпина в Государственную думу правительство внесло более 200 законопроектов, направленных на формирование правового порядка, укрепление частной собственности, местного самоуправления и защиты прав человека» [там же].

События 1917 г. и последующих годов [4, с. 78-89; 5, с. 182-185; 11, c. $35-55 ; 12$, с. $7-47 ; 13$, с. 94-103] затормозили процесс становления прав и свобод человека в России: «Октябрьская революция, приход к власти партии 
большевиков, разгон Учредительного собрания надолго отложили саму возможность пропаганды и осуществления идей прав человека в России, в их общепринятом истолковании» [3, с. 237].

Возвращение к идеям прав человека произошло в Советском Союзе только в 1930-е годы. И следующим значимым событием на пути становления прав и свобод человека Бурлацкий называет принятие Конституции СССР 1936 г. Данная конституция закрепляла целый ряд правовых норм, «направленных внешним образом на защиту права на физическую неприкосновенность, социальных прав, а также политических прав и свобод, которые даровались, однако, на условиях “укрепления коммунистического строя”» [там же]. Бурлацкий подчеркивает, что «включение в так называемую сталинскую конституцию большого блока, повторяю, внешне направленного на охрану человеческих прав, произошло под влиянием Запада и заинтересованности Сталина в нормализации отношений с демократическими государствами» [там же].

В тот период начали складываться основные отличительные черты «советской доктрины прав человека, которую представители СССР стремились проводить при заключении и принятии основных документов по этим проблемам на международной арене. Первая ее особенность заключалась в том, что полностью отрииалась идея естественных и неотчуждаемых прав личности. Эти права рассматривались, как нечто даруемое государством, при этом каждое государство могло устанавливать те нормы, которые отвечали его идеологии и интересам. Второе: претензия на "превосходство" социалистических представлений о правах человека, якобы дающих реальные гарантии их осуществления в силу характера самой системы, где нет деления на господствующие и подчиненные классы. С этих позиций подвергались критике так называемые буржуазные представления, взгляды, нормы, политическая культура, которые носят будто бы формальный характер и не обеспечиваются ни материальными условиями, ни государством.

Третье: утверждение о приоритете сочиальных прав над политическими и личными правами. Четвертое: трактовка прав человека не из универсального принципа гуманизма, не из человеческой природы, не из системы отношений между странами и государствами, а как суверенного внутригосударственного права, исключающего какое-либо международное вмешательство. Пятое: отрицание частной собственности как важнейшего права, дающего реальные гарантии независимости личности от государства и свободы инициативы и предпринимательской деятельности, как важнейшего принципа, который обеспечивает развитие личности» [3, с. 237-238].

Следующим этапом в процессе становления прав и свобод человека в России Бурлацкий называет период управления СССР Н.С. Хрущёвым: «Первый прорыв к правам человека от сталинского режима был осуществлен 
по инициативе Никиты Хрущёва, хотя он сам являлся органическим продуктом тоталитарной системы... Священное право человека на жизнь - вот главное, что гарантировали реформы Никиты Хрущёва» [3, с. 239]. Бурлацкий отмечает, что секретный доклад Н.С. Хрущёва на XX съезде КПСС о И.В. Сталине, осудивший массовые репрессии, был «крупным шагом для утверждения права на жизнь и физическую неприкосновенность советского человека. За этим последовала реабилитация и освобождение из ГУЛАГа сотен тысяч людей. В программе КПСС 1961 года были закреплены некоторые принципы, направленные на преодоление сталинской системы власти» [3, c. 240].

Активное участие в работе над этой программой принимал сам Бурлацкий. Он внес в программу положение о «переходе от диктатуры пролетариата к общенародному государству и советской демократии и о гарантиях против рецидива культа личности. Эти идеи встретили решительное сопротивление догматиков в Президиуме ЦК. О. Куусинен убедил Хрущёва в необходимости отмены стереотипа диктатуры пролетариата, что служило идеологическим обоснованием практики массовых репрессий. Затем мне было поручено возглавить рабочую группу по подготовке новой Конституции СССР. Мы проделали большую работу со специалистами и подготовили предложения по демократизации страны, учреждению президентской республики с постоянно работающим советским парламентом и либерализации внутри КПСС. Одним из боковых следствий явилось учреждение в регионах двух параллельных партийных организаций - промышленной и сельскохозяйственной. Эта идея принадлежала лично Хрущёву и означала робкий шаг к двухпартийной системе. Отстранение Хрущёва в октябре 1964 года положило конец этому этапу реформ» [3, с. 240-241].

Бурлацкий считает, что на тот момент им удалось провозгласить и частично осуществить принцип: «Не подлежат уголовному наказанию люди, высказывающие свое несогласие с властью. Хрущёв даже похвалялся: у нас нет ни одного человека, осужденного за политические преступления. Это оказалось полуправдой, но само провозглашение принципа было чрезвычайно благотворно. Второе: закончилась практика уголовных наказаний без суда. И третье: иельй слой населения - крестьянство - получил права на передвижение по стране и переселение в город или другие регионы. Началось законотворчество, которое порывало со сталинской традицией и создавало базу для становления законности. Эта деятельность, однако, осталась незавершенной, поскольку Хрущёв был отстранен от власти» [3, с. 241].

Отдельно Бурлацким охарактеризовано влияние Запада на процесс становления прав и свобод человека в Советском Союзе: «В начале 1970-х годов начался процесс улучшения отношений между СССР и США и странами Западной Европы, который привел к существенным договоренностям и сдвигам 
в области прав человека в Советском Союзе. У истоков этого процесса были соглашения, достигнутые на встречах на высшем уровне во Франции (1970, 1971 гг.), ФРГ (1971 г.) и США (1972 г.). Во время этих переговоров было согласовано решение о созыве Общеевропейского совещания по безопасности и сотрудничеству в Европе (СБСЕ)» [3, с. 241]. Третий этап этого совещания проходил с 30 июня по 1 августа 1975 г. в Хельсинки: «На нем был принят Заключительный акт, который сыграл большую роль в укреплении мира на континенте и развитии сотрудничества, в том числе в гуманитарной сфере. В совещании принимали участие 33 страны Европы, а также США и Канада» [там же].

Бурлацкий рисует следующую картину тех событий: «СССР и Запад стремились к несовпадающим целям: первый стремился закрепить границы в Европе, начать ограничение гонки вооружений; второй, кроме безопасности, был озабочен вопросом о либерализации в СССР и решением проблем прав человека, свободного передвижения товаров, людей и идей между Востоком и Западом. После успешного завершения Совещания в Хельсинки процесс был продолжен на белградской встрече (1977-1978 гг.), мадридской встрече (1980-1983 гг.)... Заключительный акт Хельсинки сыграл важную роль в ходе разрушения сталинского наследия, тоталитарного режима. Правда, происходило это больше всего в сфере идеологии, куда все шире стали проникать западные ценности относительно чести, достоинства и свободы личности» [3, с. 241-242].

Период управления СССР М.С. Горбачёвым, по мнению Бурлацкого, следующий этап в процессе становления прав и свобод человека в России: «Приход к власти Михаила Горбачёва в апреле 1985 года ознаменовал начало крутого перелома в развитии страны, в демократизации и становлении прав человека. Его деятельность отразила тенденции, объективно созревшие внутри СССР, и в то же время личные устремления Горбачёва... Первый исторический шаг - создание советского полупарламента... Это был поворот России к современной цивилизации. Тогда началось становление политики гласности, политических прав и свобод» [3, с. 243]. Бурлацкий подчеркивает, что большое значение имела «женевская встреча Горбачёва с Р. Рейганом (я [Бурлацкий] сопровождал делегации), точнее, серия встреч с западными лидерами, в особенности в Вашингтоне и Москве. Верный своей тактике, Горбачёв не делал внешне радикальных шагов и крутых поворотов. Но он последовательно шел к формированию совершенно нового типа отношений с Западом. Горбачёв все больше проникался пониманием значения прав человека для СССР» [3, с. 244].

В целом становление прав и свобод человека в Советском Союзе, по мнению Бурлацкого, можно представить как составную часть разрушения «тоталитарной системы, ее сталинской модели и утверждения демократии, 
права частной собственности и рынка. В отличие, например, от Германии, где тоталитарный режим был взорван вместе с нацистской элитой в результате поражения в войне, в СССР, а позднее в России этот процесс осуществляется сверху, представителями самой коммунистической номенклатуры и растянулся на многие десятилетия. Тоталитаризм как бы отрубался по частям, как хвост ящерицы. Этим определяется мучительный, долгий и прерывистый характер демократизации, извращение ее сущности во многих отношениях, декларативность заявленных принципов и негарантированность провозглашенных прав гражданина. Прежняя номенклатура, ее более молодая часть, осознав неизбежность все большего отставания от Запада в технологии, военном деле, экономике, вступила на зыбкую дорогу демократизации, но при этом добивалась сохранения своей власти в новых формах. Общественное движение в защиту человека едва зародилось и не могло оказать решающего влияния на этот процесс» [3, с. 215].

Бурлацкий резюмирует: «Главным фактором становления прав человека в СССР, а затем и России были внутренние изменения в стране, прежде всего разложение коммунистической идеологии и довольно бурное развитие либеральных тенденций в рамках самой политической элиты. С некоторой долей преувеличения можно было бы сказать, что духовную революцию в интереcax личной свободы произвели советники в рамках МИДа, ЦК КПСС, науки и искусства. Движение диссидентов и отказников опосредовано влияло на этот процесс именно через советников» [2, с. 235]. Далее Бурлацкий отмечает, что «решающее значение имел приход к руководству страной М. Горбачёва, который отчасти был подготовлен к восприятию демократических идей своей биографией и контактами, а в значительной мере эволюционировал к пониманию ценности человека... То же самое можно сказать о Б. Ельцине в ранний период его руководства страной» [там же].

В то же время Бурлацкий подчеркивает значение западного фактора: «России и ее деятелям негде было взять пример, юридическую и правовую культуру кроме как на Западе и в международном праве, которое также формулировалось под влиянием западных идей. Этот фактор сыграл решающую роль в просвещении и советников, и вождей...» [2, с. 235]. Бурлацкий добавляет, что международный фактор сыграл «огромную роль в эпоху реформации в России. Наступила внутренняя эрозия коммунизма, его идеологии. Коммунистическая номенклатура, вернее, ее продвинутая культурно часть, стала задумываться над преимуществами западной экономики и системы ценностей. Началась революция сверху, выплеснувшая таких новых деятелей, как Горбачёв и Ельцин» [2, с. 236].

Бурлацкий считает, что схожими причинами объясняются и «все ошибки, и извращения демократических реформ. Старая партийная и молодая комсомольская номенклатура повернула их в сторону личного обогащения, сохранив 
в значительной степени бесправие народа и попутно раздавив демократическую интеллигенцию. Провал молодых радикальных демократов, которые привели экономику к тяжелейшему кризису летом 1998 года, создал предпосылки для движения политического маятника в другую сторону. Центристское правительство Е. Примакова попыталось укрепить политическую стабильность и сохранить завоевания прав человека. Однако преодолеть глубокий экономический кризис не смогло» [2, с. 236-237].

\section{Практическая реализация идей и преаложений Ф.М. Бурлацкого}

Уникальность личного опыта Бурлацкого состоит в том, что ему удалось реализовать часть своих идей и предложений на практике. В 1987 г. под руководством Бурлацкого была создана Комиссия по гуманитарному сотрудничеству и правам человека при Советском комитете за европейскую безопасность и сотрудничество. В состав Комиссии вошли ученые, деятели культуры и представители религиозных конфессий, впоследствии внесшие значительный вклад в развитие доктрины обеспечения прав и свобод человека и формирование правозащитных институтов.

Комиссия занималась разрешением различного рода вопросов, касающихся защиты прав и свобод человека, проводила разного формата конференции, встречи, семинары. Поэтому ее можно считать предтечей различных правозащитных организаций России [2, с. 89]. Далее на основе этой комиссии была создана международная правозащитная организация - «Дебургское движение по правам человека», позже оно получило название «ВосточноЗападная конференция по правам человека». Сопредседателями конференции были: от СССР - Бурлацкий и от США - Р. Картер. Наибольшую известность Дебургскому движению принесло отстаивание прав и требование освобождения осужденных за так называемые религиозные преступления.

В этот период Бурлацким была подготовлена аналитическая записка в адрес члена Политбюро ЦК КПСС, Секретаря ЦК КПСС А.Н. Яковлева, в которой обосновывалась необходимость поднятия статуса Комиссии по гуманитарному сотрудничеству и правам человека, приравняв ее к имеющимся общественным Комитетам (мира, за европейскую безопасность и др.); возложить на Комиссию осуществление ряда мероприятий вместе с представителями партийных и правоохранительных органов; возложить на Комиссию осуществление целенаправленных мероприятий на международной арене, имеющих целью перехватить инициативу и перейти в наступление в этой области и др. [1, л. 8-9].

В 1989 г. Бурлацкий был избран народным депутатом и стал членом Комитета Верховного Совета СССР по международным делам. В рамках коми- 
тета, по его инициативе, был создан подкомитет по гуманитарному, научному и культурному сотрудничеству, руководство которым было поручено самому Бурлацкому. Результатом деятельности Бурлацкого в направлении обеспечения гарантий прав и свобод человека стали подготовленные под его руководством и вступившие в силу законы: о свободе передвижения, о свободе средств массовой информации и о свободе совести и религиозных организациях, а также «Декларация прав и свобод человека» [15]. 22 ноября 1991 г. Верховный Совет РСФСР утвердил Декларацию прав и свобод человека и гражданина. Многие положения данной декларации были внесены в проект Конституции РФ 1993 г.

Таким образом, Бурлацкий вел активную деятельность, направленную на становление прав и свобод человека: способствовал созданию Комиссии по гуманитарному сотрудничеству и правам человека при Советском комитете за европейскую безопасность и сотрудничество. Работая депутатом Верховного Совета СССР, Бурлацкий участвовал в подготовке и принятии законов, гарантирующих права и свободы человека в Советском Союзе.

Все сказанное позволяет сделать вывод о том, что Бурлацкий не только исследовал процесс становления прав и свобод человека в России, но и внес идейный вклад в него, а также смог реализовать часть своих предложений на практике.

\section{Библиография}

1. Бурлацкий Ф.М. Записка члену Политбюро ЦК КПСС, Секретарю ЦК КПСС А.Н. Яковлеву // ОРКиР НБ МГУ. Ф. 61. Оп. 1. Д. 3. Л. 1-9.

2. Бурлацкий Ф.М. Проблемы прав человека в СССР и России. (1970-80-е и начало 90-х годов). М.: Научная книга, 1999. 279 с.

3. Бурлацкий Ф.М. Реформы и реформаторы: Надежды и иллюзии. М.: Собрание, 2008. $319 \mathrm{c}$.

4. Гуторов В.А. О некоторых тенденциях современной теоретической интерпретации революционного насилия // Философия политики и права. 2017. № 8. С. 78-89.

5. Ильин М.В. Язык революции - язык улицы // Полис: Политические исследования. 2010. № 6. С. 182-185.

6. Карташкин В.А. Опыт разработки и принятия пактов о правах человека и современные международные отношения // Образование и право. 2016. № 11. С. 24-29.

7. Кудрявцев М.А. Институт парламентского уполномоченного по правам человека в России: Проблемы становления и развития // Труды Института государства и права Российской академии наук. 2017. Т. 12. № 3. С. 101-123.

8. Перевезенцев С.В. Основные направления русской социально-политической мысли XVIII в. // Каспийский регион: Политика, экономика, культура. Астрахань, 2016. № 3. С. 9-17.

9. Перевезенцев С.В. Родство по истории: Статьи. Очерки. Беседы. М.: Издательство «ФИВ», 2015. $456 \mathrm{c}$.

10. Перевезенцев С.В. Русский выбор: Очерки национального самосознания. М.: Русский мир, 2007. $416 \mathrm{c}$. 
11. Пивоваров Ю.С. Истоки и смысл русской революции // Полис: Политические исследования. 2007. № 5. С. 35-55.

12. Пивоваров Ю.С. Русская литература - русская революция // Литературоведческий журнал. 2017. № 41. С. 7-47.

13. Пляйс Я.А. Два подхода к российским революциям 1917 года: Какой из них верен? Концептуальные размышления о судьбах российских революций 1917 года // Научноаналитический журнал Обозреватель - Observer. 2017. № 9 (332). С. 94-103.

14. Понизова Е.В. Институт правового статуса личности в период перестройки // Труды Института государства и права Российской академии наук. 2016. № 6 (58). С. 191-206.

15. Соболев В.А. Ф.М. Бурлацкий и перестройка в СССР // Вестник Московского государственного областного университета (Электронный журнал). 2018. № 2. URL: http://evestnikmgou.ru/ru/Articles/View/875 (Дата обращения: 17.04.2018.)

16. Соболев В.А., Ширинянц А.А. Ф.М. Бурлацкий и становление политической науки в СССР // Политическая наука. 2016. № 5. С. 25-42.

17. Шестопал Е.Б., Шутов А.Ю. Памяти Ф.М. Бурлацкого (1927-2014) // Вестник Московского университета. Серия 12: Политические науки. 2014. № 3. С. 124-128.

18. Ширинянц А.А. Интеллигенция в политической истории XIX века // Вестник Московского университета. Серия 12: Политические науки. 2012. № 4. С. 39-55.

19. Ширинянц А.А. Нигилизм или консерватизм? (Русская интеллигенция в истории политики и мысли). М.: Издательство Московского университета, 2011. 563 с.

20. Ширинянц А.А., Ширинянц С.А. Российская интеллигенция на рубеже веков: заметки о политической культуре. М.: Изд-во Московского университета, 1997. 160 с.

\section{References}

Burlackij F.M. Problemy prav cheloveka v SSSR i Rossii. (1970-80-e i nachalo 90-h godov). Moscow: Nauchnaja kniga, 1999. 279 p.

Burlackij F.M. Reformy i reformatory: Nadezhdy i illjuzii. Moscow: Sobranie, 2008. 319 p.

Burlackij F.M. Zapiska chlenu Politbjuro CK KPSS, Sekretarju CK KPSS A.N. Jakovlevu // ORKiR NB MGU. F. 61. Op. 1. D. 3. L. 1-9.

Gutorov V.A. O nekotoryh tendencijah sovremennoj teoreticheskoj interpretacii revoljucionnogo nasilija // Filosofija politiki i prava. 2017. N 8. P. 78-89.

Il'in M.V. Jazyk revoljucii - jazyk ulicy // Polis: Politicheskie issledovanija. 2010. N 6. P. 182185.

Kartashkin V.A. Opyt razrabotki i prinjatija paktov o pravah cheloveka i sovremennye mezhdunarodnye otnoshenija // Obrazovanie i pravo. 2016. N 11. P. 24-29.

Kudrjavcev M.A. Institut parlamentskogo upolnomochennogo po pravam cheloveka v Rossii: Problemy stanovlenija i razvitija // Trudy Instituta gosudarstva i prava Rossijskoj akademii nauk. 2017. Vol. 12. N 3. P. 101-123.

Perevezencev S.V. Osnovnye napravlenija russkoj social'no-politicheskoj mysli XVIII v. // Kaspijskij region: Politika, jekonomika, kul'tura. Astrahan', 2016. N 3. P. 9-17.

Perevezencev S.V. Rodstvo po istorii: Stat'i. Ocherki. Besedy. Moscow: Izda-tel'stvo «FIV», 2015. $456 \mathrm{p}$.

Perevezencev S.V. Russkij vybor: Ocherki nacional'nogo samosoznanija. Moscow: Russkij mir, 2007. $416 \mathrm{p}$.

Pivovarov Ju.S. Istoki i smysl russkoj revoljucii // Polis: Politicheskie issledovanija. 2007. N 5. P. $35-55$ 
Pivovarov Ju.S. Russkaja literatura - russkaja revoljucija // Literaturovedcheskij zhurnal. 2017. N 41. P. 7-47.

Pljajs Ja.A. Dva podhoda k rossijskim revoljucijam 1917 goda: Kakoj iz nih veren? Konceptual'nye razmyshlenija o sud'bah rossijskih revoljucij 1917 goda // Nauchno-analiticheskij zhurnal Obozrevatel' - Observer. 2017. N 9 (332). P. 94-103.

Ponizova E.V. Institut pravovogo statusa lichnosti v period perestrojki // Trudy Instituta gosudarstva i prava Rossijskoj akademii nauk. 2016. N 6 (58). P. 191-206.

Shestopal E.B., Shutov A.Ju. Pamjati F.M. Burlackogo (1927-2014) // Vestnik Moskovskogo universiteta. Serija 12: Politicheskie nauki. 2014. N 3. P. 124-128.

Shirinjanc A.A. Intelligencija v politicheskoj istorii XIX veka // Vestnik Moskovskogo universiteta. Serija 12: Politicheskie nauki. 2012. N 4. P. 39-55.

Shirinjanc A.A. Nigilizm ili konservatizm? (Russkaja intelligencija v istorii politiki i mysli). Moscow: Izdatel'stvo Moskovskogo universiteta, 2011. 563 p.

Shirinjanc A.A., Shirinjanc S.A. Rossijskaja intelligencija na rubezhe vekov: zametki o politicheskoj kul'ture. Moscow: Izd-vo Moskovskogo univer-siteta, 1997. 160 p.

Sobolev V.A. F.M. Burlackij i perestrojka v SSSR // Vestnik Moskovskogo gosudarstvennogo oblastnogo universiteta (Jelektronnyj zhurnal). 2018. N 2. URL: http://evestnik-mgou.ru/ru/Articles/ View/875 (Data obrashhenija: 17.04.2018.)

Sobolev V.A., Shirinjanc A.A. F.M. Burlackij i stanovlenie politicheskoj nauki v USSR // Politicheskaja nauka. 2016. N 5. P. 25-42. 